\title{
The Artist-Shaman and Primitivism
}

\section{Dr. Louis Laganà, University of Malta, Malta}

\begin{abstract}
One may ask: What is the relationship between shamanic artists and contemporary artists working on prehistoric models? Few recognise that the relationship actually is very important. I feel that many contemporary artists use traditional shamanic techniques to achieve the spiritual and metaphysical content in their work. It has been said that certain works by individual artists could heal or benefit an audience of viewers or an entire community. Unfortunately few artists regarded prehistoric and other forms of 'primitive' art with a potent shamanic content. Many are more interested in the formal aspect. Some of these artists engage themselves in private and painful 'vision quests' in their secular search for the sacred. This is why I see that an aspect of Shamanism is being practised today by some contemporary artists, in order to restore and show society the lost spiritual visions of life. One has also to keep in mind that a number of artists are not conscious of themselves as being 'shamans' and those who relate to this shamanic quest may at times use shamanic imagery without being aware of its content.
\end{abstract}

Keywords: Artist-Shaman, Prehistoric Art, Contemporary Art, Primitivism, Myth, Spiritual Quest

\section{Introduction: Definition of Shamanism}

Shamanism is an ancient spiritual practice that dates back to prehistoric times, around 10,000 to 40,000 years. It is based on animism, which explains that everything on earth has a spiritual essence. Ancient people believed that life and survival depended on keeping a relationship between the natural and the spiritual worlds. The role of the shaman was as an intermediary between the visible and invisible worlds. Archaeologist, Paul G. Bahn, confirms this and describes the shaman as

a very important figure, being a person with spiritual powers who may combine the roles of healer, priest, magician and (sometimes) artist, as well as poet, actor, fortune-teller, weather-controller and even psychotherapist. His most important function is to act as liaison between this world and the spirit world, a task usually performed by means of trances and hallucinatory experiences - either selfinduced or usually hallucinogenic fungi or other similar substances. ${ }^{1}$

\footnotetext{
${ }^{1}$ BAHN, Paul,G., Prehistoric Art, 1998, pp. 235, 236.
} 
Shamans exercised their powers also in art. Nearly in every continent we find 'shamanic' artistic expression, which started thousands of years ago. It is mainly found in two forms: stone carvings - petroglyphs, and paintings - pictographs. Archaeologists attribute most of their finds of ancient art to religious or cultic practices in which the shaman was essential. Shamans used symbolism in most of their paintings and carvings, expressing and interacting with the realm of the spiritual world. The symbolic repertoire of the shaman is vast and it is often mysterious and difficult to conceive. A good example of shamanism is strong in the art of the Late Neolithic period in Malta. One may find evidence of a cache of nine stone idols, known as the 'Shaman's Bundle' (Fig. 01) found in one of the tombs at the Brochtorff Circle in Gozo. Eight of these artefacts represent human figures. "The context of the discovery suggests that these objects were the paraphernalia employed by shamans, probably in conjunction with the death cult." 2 There is also evidence of traces of red-ochre on many artefacts, bones and structures of temples sites that show the practice of shamanism. It is argued that the Maltese prehistoric shaman performed also the role of an artist. One cannot separate the shaman and the artist. It is probable that shamans produced most artefacts like statuettes and other ornaments used in the rituals of fertility and the death cults.

In his first book, the first volume, of the series "The Masks of God - Primitive Mythology" Joseph Campbell refers to the prehistoric artist-shamans as visionaries who project their work through public ceremonies and ritual. "The healing of the shaman is achieved through art: i.e., mythology and song."3 Perhaps one of the greatest scholars on Shamanism is Mircea Eliade. In his seminal book Shamanism: Archaic Techniques of Ecstasy, Eliade defines Shamanism as a way to attain "techniques of ecstasy." His concept of "soul flight" is identified as the state where the shaman enters an ecstatic trance, and travels to the realms of the Spirit. The visions of shamans are recorded in "poetry, song, and the visual arts for the spiritual and therapeutic benefit of the community." Such visions are achieved through trance and enter into the realm of myth. Joseph Campbell points out: "The realm of myth, from which, according to primitive belief, the whole spectacle of the world proceeds, and the realm of shamanistic trance are one and the same." So myth is an important aspect of the 'shaman's inner experience' and the way he expresses himself in his rituals. This shamanic experience could also be applied to the modern and contemporary artist.

2 SAVONA VENTURA, Charles, Medical Mythology of Prehistoric Man in Malta, in MIFSUD, Anton, and SAVONA VENTURA, Charles, Facets of Maltese Prehistory, 1999, p. 114, se also MALONE, C., et al, The Death Cults of Prehistoric Malta, in Scientific American, 269, pp. 76-83.

${ }^{3}$ CAMPBELL, Joseph, The Masks of God-Primitive Mythology, p.265.

${ }^{4}$ ELIADE, Mircea, Shamanism: Archaic Techniques of Ecstasy, 1964, p.4.

${ }^{5}$ LEVY, Mark, Shamanism and the Modern Artist - Technicians of Ecstasy, 1993, p xv, (introduction).

${ }^{6}$ CAMPBELL, Joseph, The Masks of God-Primitive Mythology, p. 250. 


\section{Myth and Shamanism}

Michael Tucker in his scholarly book about Shamanism and Modern Art: Dreaming with open eyes - the Shamanic Spirit in Twentieth Century Art and Culture, argues:

For Eliade, as for Joseph Campbell (another major interpreter of primitivistic ideas whose work has been curiously - not to say scandalously - neglected by recent critics of primitivism), the key to that conversation lay in a sensitivity to the layers of meaning that lie within myth. ${ }^{7}$

I agree with what Tucker suggests about the importance of myth between 'archaic thought' and 'modern art'. He discusses the way certain critics of primitivism describe the term 'myth' in twentieth-century art as 'falsehood' (taking the interpretation of Roland Barthes as 'false-consciousness'). Tucker also referred to Frank Kermode's difference between 'fiction' and 'myth', giving a definition of fiction contrary to the definition of myth. The first is "an agent of change" and the latter "an agent of stability." 8 Michael Tucker brings out strongly his interpretation:

Contrary to both Barthes and Kermode, we may find that the essentially metaphoric nature of the myth-infected thought and imagery of primitivistic art this century neither 'naturalises' nor stabilises' things, but rather precipitates psychological change and growth. Enhanced sensitivity to the mythic dimensions of life need not signify 'false-consciousness': on the contrary, it can open up far deeper and richer layers of consciousness than the purely historical mode of existence which has come to dominate so much of life today. ${ }^{9}$

I find the definition of myth as described by Joseph Campbell as the most compelling. He explained these four functions of myth: Metaphysical-Mystical, Cosmological, Sociological and Psychological. ${ }^{10}$ Campbell's definition of myth is broader and more dynamic than that of his predecessors. He argued that all myth is linked to the human psyche. The study of Freudian and Jungian theories provides the best searching tool to make a deep and thoughtful interpretation of mythology. I believe that you cannot separate the study of myth from the study of religious beliefs and rituals. Perhaps the greatest scholar of religion who made serious studies on the 'sacredness' of mythology is Mircea Eliade whom I have already mentioned. Eliade gives a clear definition of myth as follows:

Myth narrates a sacred history; it relates an event that took place in primordial Time, the fabled time of the 'beginnings'. In other words, myth tells how, through the deeds of Supernatural Beings, a reality came into existence, be it the whole of reality, the Cosmos, or only a fragment of reality - an island, a species of plant, a particular kind of human behavior, an institution. Myth, then, is always an account of a 'creation'; it relates how something was produced, began to be. Myth

\footnotetext{
${ }^{7}$ TUCKER, Michael, Dreaming with open eyes - the Shamanic Spirit in Twentieth Century Art and Culture, 1992, p.6.

${ }^{8}$ Ibid.,p.7.

${ }^{9}$ Ibid., pp. 7,8.

${ }^{10}$ See the definition of myth by CAMPBELL, Joseph, The Masks of God - Creative Mythology, 1968, pp. 609-624.
} 
tells only of that which really happened, which manifested itself completely. The actors in myths are Supernatural Beings. They are known primarily by what they did in the transcendent times of the 'beginnings'. Hence myths disclose their creative activity and reveal the sacredness (or simply the 'supernaturalness') of their works. In short, myths describe the various and sometimes dramatic breakthroughs of the sacred (or the 'supernatural') into the World. ${ }^{11}$

Eliade explained myth as a derivative of "truth and reality" and therefore it is a breakthrough of the sacred that really established the World and makes it what it is today. "Myth is regarded as a sacred story, and hence a 'true history', because it always deals with realities."12

Joseph Campbell, an authority and analyst of myth, is considered to be romantic in his approach to the theory of myth. "His romantic view of myth is the opposite of a rationalist view." ${ }^{\prime 4}$ Robert Segal, professor of religious studies, explains the contrasts and differences that exist between the rationalists' idea of myth and that presented by Campbell. "Rationalists believe that science better serves its explanatory function than myth, romantics believe that nothing duplicates the psychological or metaphysical content of myth." ${ }^{15}$ Rationalists hold the idea that myth is a 'primitive' explanation of the physical world; therefore myth and science are incompatible. "To rationalists, science makes myth both unnecessary and impossible for moderns, who by definition are scientific." $"$ This is contrary to what Campbell maintained. Even Carl Jung disagreed with the rationalists. He said: "No science will ever replace myth, and myth cannot be made out of science." 17 Segal continues to point out that Campbell's theory of myth goes far beyond the explanation of the physical world. He stated:

The scope of his definition of myth guarantees its irreplaceability. Dreams, ritual, art, literature, ideology and science become varieties of myth rather than alternatives to it. An action as well as a belief can be mythic, and the belief need not take the form of a story, which itself can be of any kind. ${ }^{18}$

Joseph Campbell had great admiration for the primitives maintaining that they understood myths more than 'moderns'. 'Moderns' had to apply depth psychology to understand myths. ${ }^{19}$ Although there are still disputes amongst theorists of myth about its definition and function, the importance of myth in modern society still seems to be very relevant. Campbell argues that "moderns as well as primitives not merely can but must have myth." 20

\footnotetext{
${ }^{11}$ ELIADE, Mircea, Myth and Reality, 1963, pp. 5-6, Harper and Row, New York.

12 Ibid., p.6.

${ }^{13}$ SEGAL, Robert, The Romantic Appeal of Joseph Campbell, in Christian Century, April 4, 1999, pp.332335.

14 Ibid.

15 Ibid.

${ }^{16}$ Ibid.

${ }^{17}$ JUNG, C.G., Memories, Dreams and Reflections, (first published in 1963), 1995 edition, p. 373.

${ }^{18}$ SEGAL, Robert, The Romantic Appeal of Joseph Campbell, in Christian Century, April 4, 1999, pp. 332-335.

${ }^{19}$ Ibid.

${ }^{20}$ Ibid.
} 


\section{The Shaman and the Modern Artist}

To go back to the role of the artist-shaman, an excellent example of the relationship between the shaman and the modern artist is clearly given by Mark Levy in his book: Shamanism and the Modern Artist - Technicians of Ecstasy. He sees the shaman as a 'sensitive' individual with great ability to maintain vital contact with the spirit world. If this fails this may lead to "nervous disorders" if the shaman is not well trained. ${ }^{21}$ Levy argues that

Artists also require a heightened sensitivity to themselves, the world around them, as well as to color and form. Like shamans, many artists have enhanced powers of seeing, hearing, and dreaming and move easily between different realities, not experiencing the boundaries that many of us been acculturated to accept. ${ }^{22}$

For Levy, the artist, like the shaman, has a special spiritual 'call' that would be risky to him if neglected. He sees and finds the 'call' in shamanism related to an artistic process. ${ }^{23}$ "Artists are often compelled to express themselves and the failure to do so can bring about a crisis." 24 Both the shaman and the artist have emotional, sensitive and spiritual qualities that are expressed in their work. It is also known that shamanism provides healing, therapy and advice on certain human conditions related to spirituality through the use of altered states of consciousness. Shamanism is not a religion but rather describes an approach to spirituality.

The idea that the artist-shaman has healing powers is well known and commented on by some art historians. Suzi Gablik believes in "the ancient healing function of art." 25 Today's society needs artists more than before to heal the world from its material and spiritual crisis. So the artist's role becomes more like that of a shaman, who was a "mystical, priestly, and political figure in prehistoric cultures, who, after coming close to death through accident or severe illness, becomes a visionary and a healer." 26 Gablik continues to emphasize, "the shaman's function is to balance and centre society, integrating many planes of life-experience, and defining the culture's relationship to the cosmos." 27 When the 'divine' and the 'human' fall out of balance, "it is the shaman's responsibility to restore the lost harmony and re-establish equilibrium." ${ }^{28}$ The need for a universal type of healing was being felt because of the dissatisfaction with modernism and the loss of the spiritual values of humanity. Gablik suggests:

The artist as shaman becomes a conductor of forces which go beyond those of his own person, and is able to bring art back in touch with its sacred sources; through

\footnotetext{
${ }^{21}$ LEVY, Mark, Shamanism and the Modern Artist-Technicians of Ecstasy, 1993, p xvi (introduction).

22 Ibid.

23 Ibid.

24 Ibid.

${ }^{25}$ GABLIK, Suzi, Has Modernism Failed? , 1984, p. 124.

${ }^{26}$ Ibid., p. 126.

27 Ibid.

${ }^{28}$ Ibid.
} 
his own personal self-transformation, he develops not only new forms of art, but new forms of living. ${ }^{29}$

There are writers who argue differently about the role of the artist-shaman in today's life. Referring to the idea of one of his colleagues, Ruth-Inge Heinze (who studied shamanism), Mark Levy points that "unlike traditional shamans, modern artists are not available, on a daily basis, nor do they receive a 'call' or attempt to solve mundane problems of individuals or the community." 30 The role of the artist-shamans could be also interpreted not as a necessary function as healers of the community but as an "attempt to heal themselves rather than respond to the daily needs of their contemporaries." 31 To give some examples, one can refer to works, like the Earthworks, by artist by Robert Smithson's Spiral Jetty of 1970, and the performances as rituals by Joseph Beuys who made direct references to the conceptual aspect of Primitive art. These artists considered their work as a return to society and that "art was becoming, as Primitive art had been, more integrally engaged with broader systems of nature, magic, ritual, and social organization." ${ }^{, 32}$ These art works are used to address the 'human trauma' and are meant to heal the spectators. Art historian, Donald Kuspit refers to Robert Smithson's Spiral Jetty (1970) and the 'intimate' scale of the sleds in Beuys' The Pack (1969), which have a healing power to those who have a visual experience of these works. "Walking along the Spiral Jetty, in effect at the edge of the world, one has a self-transformative transcendental experience. One is in the great beyond, liberated from the cares of the lifeworld." 33 In her seminal book on contemporary art and the art of prehistory, Overlay, art historian, Lucy Lippard also hints that walking along the Spiral Jetty is like the reverberation of primitive initiation rites. ${ }^{34}$ In Beuys's sculpture one could sense the Shamanistic ritual and a response to the deterioration of nature and the effects of the Second World War on humanity. "The fat and felt with which the sleds are equipped -along with a flashlight to see in the dark -- are the animal materials that healed his warshattered self and body." 35 Both artists are 'Romantic' primitivists because their art was rooted in a modern world full of disillusion and discontent with society and used their art as a means to retrieve a new sense of spirituality. The symbolical part of their works became the means to explore the unlimited power of the unconscious mind.

\footnotetext{
${ }^{29}$ Ibid.

${ }^{30}$ LEVY, Mark, Shamanism and the Modern Artist - Technicians of Ecstasy, 1993, p xvii (introduction).

31 Ibid.

${ }^{32}$ VARNEDOE, Kirk, Contemporary Explorations, in RUBIN, William, "Primitivism in 20th Century

Art”, 1984, Vol. II., p.662.

${ }^{33}$ KUSPIT, Donald, A Critical History of 20th Century Art, in Artnet Magazine Chapter 7, Parts 4 \& 5 , http://www.artnet.com/magazineus/features/kuspit/kuspit7-21-06.asp

${ }^{34}$ LIPPARD, Lucy, Overlay: Contemporary Art and the Art of Prehistory, 1983, p. 225

${ }^{35}$ KUSPIT, Donald, A Critical History of 20th Century Art, in Artnet Magazine Chapter 7, Parts 4 \& 5 , http://www.artnet.com/magazineus/features/kuspit/kuspit7-21-06.asp
} 
In the context of modern art 'Prehistoric' primitivism ${ }^{36}$ maintains a compelling attitude to what has been forgotten about art. It is an art that reveals the responses to the environment and mythologizing concepts. As I have already stated, I understand that the prehistoric artist's role had two functions. First that he made objects for utilitarian domestic purposes, his work was like that of a craftsman, an artisan relying on the natural environment as resources for ideas and materials, and the second function is more attributed to the role of an artist-shaman. Perhaps the latter aspect influenced the modern artist to become attracted to prehistoric times for the mythologizing and animistic powers that prehistoric artists held. For example, this is seen in the work of Henry Moore. His 'spiritualized' figures: standing, reclining and seated, most of them representing the goddess or mother and child are all reflections of his vision of the landscape, rock formation and prehistoric monuments found in Yorkshire and other parts of Britain. Moore's work is a direct response to 'life'. In his commentary about 'Primitive Art' he wrote:

The most striking quality common to all primitive art is its intense vitality. It is something made by people with a direct and immediate response to life. Sculpture and painting for them was not a calculation or academism, but a channel for expressing powerful beliefs, hopes and fears. ${ }^{37}$

The animistic sensibility of the artist is expressed in his sculptures through simplification of form. Moore loved the innate sculptural sense of the prehistoric, early Bronze Age, Cycladic marble figurines of women. He was inspired by these naked idols with folded arms and produced fascinating variations of remarkable studies of the female form, in wood, bronze and marble.

Today, we find the shamanic content in the works of a vast array of visionary and outsider artists who are inspired by Prehistoric art. These artists are not concerned about expressing prehistoric symbols and dream imagery just for the sake of re-creating the past, but use 'primitive' imagery as a vehicle to capture back the lost values, which are aimed to heal human life and the earth. As Marianna Torgovnick points out, "The primitive can be a channel for spirituality outside of organized religion; the primitive can be one route in the quest for ecstatic contact with the essence of life." 38 Therefore I see the role of contemporary artist-shamans in a dual perspective. They are the healers of society, spiritual guides of the community and also being conscious of themselves, they are capable of self-transformation and self-realization. Because artists are isolated in our society, there is the need for a psychological necessity to survive and bring back selfesteem. $^{39}$ So I believe that first the artist, as an individual needs to heal himself, then through this work starts the process of healing society. "Artists can create new forms that

\footnotetext{
${ }^{36}$ See the discussion on 'Prehistoric' Primitivism in LAGANÀ, Louis, Prehistoric Malta and Contemporary Art, Ph.D. dissertation submitted to the School of Art and Design, Loughborough University, January 2005, unpublished, pp 163-168.

${ }^{37}$ MOORE, Henry, on Primitive Art, in WILKINSON, Alan, Henry Moore: Writings and Conversations, p.103, 2002, Lund Humphries Publishers.

38 TORGOVNICK, Marianna, Primitive Passions, 1996, p. 109.

${ }^{39}$ LIPPARD, Lucy, Overlay: Contemporary Art and the Art of Prehistory, 1983, p. 6.
} 
are appropriate to modern life and these forms also have a powerful shamanic content."40 These artists still have an important role to accomplish in today's life.

\section{References}

BAHN, Paul,G., Prehistoric Art, 1998, Cambridge University Press.

CAMPBELL, Joseph, The Masks of God - Primitive Mythology, date, Souvenir Press.

ELIADE, Mircea, Shamanism: Archaic Techniques of Ecstasy, 1964, NJ: Princeton

University Press.

ELIADE, Mircea, Myth and Reality, 1963, pp. 5-6, Harper and Row, New York.

GABLIK, Suzi, Has Modernism Failed?, 1984, Thames and Hudson.

JUNG, C.G., Memories, Dreams and Reflections, (first published in 1963), 1995 edition, Fontana Press.

KUSPIT, Donald, A Critical History of 20th Century Art, in Artnet Magazine Chapter 7, Parts 4 \& 5, http://www.artnet.com/magazineus/features/kuspit/kuspit7-21-06.asp LAGANÀ, Louis, Prehistoric Malta and Contemporary Art, Ph.D. dissertation submitted to the School of Art and Design, Loughborough University, 2005.

LEVY, Mark, Shamanism and the Modern Artist - Technicians of Ecstasy, 1993, Bramble Books, Connecticut, U.S.A.

LIPPARD, Lucy, Overlay: Contemporary Art and the Art of Prehistory, 1983, publisher MALONE, C., et al, The Death Cults of Prehistoric Malta, in Scientific American, 269. SAVONA VENTURA, Charles, Medical Mythology of Prehistoric Man in Malta, in MIFSUD, Anton, and SAVONA VENTURA, Charles, Facets of Maltese Prehistory, 1999, Prehistoric Society of Malta.

MOORE, Henry, on Primitive Art, in WILKINSON, Alan, Henry Moore: Writings and Conversations, 2002, Lund Humphries Publishers.

SEGAL, Robert, The Romantic Appeal of Joseph Campbell, in Christian Century, April 4, 1999.

TORGOVNICK, Marianna, Primitive Passions, 1996, The University of Chicago Press. TUCKER, Michael, Dreaming with open eyes - the Shamanic Spirit in Twentieth Century Art and Culture, 1992, Aquarian/Harper, Collins.

VARNEDOE, Kirk, Contemporary Explorations, in RUBIN, William, "Primitivism in 20th Century Art", 1984, Vol. II., The Museum of Modern Art, New York.

(C) Dr. Louis Laganà and The International Journal of the Arts in Society - Common Ground Publishers.

\footnotetext{
${ }^{40}$ LEVY, Mark, Shamanism and the Modern Artist-Technicians of Ecstasy, 1993, p. 4.
} 
The 5th International Conference on the Arts in Society University of Sydney

Australia

Email: louis.lagana@um.edu.mt

22-25 July 2010 